\title{
Methodology for development of a seaport: the case study of Kozhikode seaport (India)
}

\author{
V. Ansu ${ }^{1} \&$ M. V. L. R. Anjaneyulu ${ }^{2}$ \\ ${ }^{1}$ Government Engineering College Kozhikode, Kerala, India \\ ${ }^{2}$ National Institute of Technology Calicut, Kerala, India
}

\begin{abstract}
At present, bigger vessels anchor in the outer sea at Beypore seaport, Kozhikode due to inadequate draught. Smaller vessels transport the freight from these bigger vessels to the harbor resulting in unnecessary expenditure. Thus, many commodities are diverted to the nearby major ports resulting in needless traffic on the highways connecting these ports increasing traffic congestion and accidents. Hence the development of Kozhikode seaport is essential in order to enable bigger vessels to berth. Stated preference surveys conducted to estimate the future traffic after development estimated that the freight traffic will multiply 15 fold, resulting in a tremendous increase in seaport revenue, huge profits for the shippers and massive benefits to society. The facilities needed at the seaport were estimated by queuing theory. The cost benefit analysis revealed that the project is viable and results in a sustainable future.
\end{abstract}

Keywords: planning and development of seaport, sustainable transportation.

\section{Introduction}

From time immemorial, people have been anxious about the world beyond great seas and started to travel in ships. Hence, seaports became essential for these vessels to harbour in tranquillity. Sea navigation also became essential for trade and defence. Efficient movement of freight is important for promoting international trade in the current globalized market. Freight transportation by sea is very economical as it is highly energy efficient. Seaports should be able to handle large vessels with modern freight handling equipment for efficient handling of containerised cargo. But it is difficult to develop the old seaports as they have insufficient draught shallow foundation depths. The development of 
seaport needs huge capital and can be justified only if it delivers more benefits to the society than the costs. This paper presents a systematic methodology for the development of an old seaport and its economic appraisal. Kozhikode seaport at Beypore is selected for the case study.

\subsection{Kozhikode seaport}

India has 14 major ports and 187 minor ports with a coastline of $7517 \mathrm{Km}$ (IPA [1]). The minor and intermediate ports serve as buffer for the major ports reducing the congestion by accommodating the local traffic and coastal shipping. Kozhikode seaport is one of the oldest seaports having trade with foreign countries. Arab traveller Ibn Battūtah, who visited Kerala during 1342-47, described Kozhikode as the seaport where a large number of vessels from different parts of the world can be seen. Kozhikode attained excellent position in the trade of pepper and other spices, which made it India's emporium of foreign trade. As the rulers of Kozhikode offered full freedom, the Arab and the Chinese merchants preferred it to all other ports in India. Kozhikode was much sought after by merchants from Western Asia, for its wooden ship building industry.

\begin{tabular}{|c|c|}
\hline \multicolumn{2}{|c|}{ Study of problems at the seaport } \\
\hline$\downarrow$ & $\downarrow$ \\
\hline Do-nothing Scenario & $\begin{array}{l}\text { Development Scenario - } 15 \mathrm{~m} \\
\text { draught }\end{array}$ \\
\hline$\downarrow$ & $\downarrow$ \\
\hline $\begin{array}{l}\text { Data Collection } \\
\text { - Collection of time series freight } \\
\text { data and present facilities }\end{array}$ & $\begin{array}{l}\text { Data collection } \\
\text { - Stated preference survey of major } \\
\text { shippers }\end{array}$ \\
\hline$\downarrow$ & $\downarrow$ \\
\hline $\begin{array}{l}\text { Data analysis } \\
\text { - Analysis of present freight traffic }\end{array}$ & $\begin{array}{l}\text { Data analysis } \\
\text { - Assessment of total attracted } \\
\text { traffic to Kozhikode seaport }\end{array}$ \\
\hline$\downarrow$ & $\downarrow$ \\
\hline $\begin{array}{l}\text { Traffic forecasting by time series } \\
\text { modelling }\end{array}$ & $\begin{array}{l}\text { Traffic forecasting based on } \\
\text { economic indicators }\end{array}$ \\
\hline$\downarrow$ & $\downarrow$ \\
\hline \multicolumn{2}{|c|}{ Determination of total traffic } \\
\hline \multicolumn{2}{|c|}{$\downarrow$} \\
\hline \multicolumn{2}{|c|}{ Estimation of berths needed for different class of vessels by queuing theory } \\
\hline \multicolumn{2}{|c|}{$\downarrow$} \\
\hline \multicolumn{2}{|c|}{ Design of new Kozhikode seaport } \\
\hline \multicolumn{2}{|c|}{$\downarrow$} \\
\hline Economic appraisa & ost benefit analysis \\
\hline
\end{tabular}

Figure 1: $\quad$ Methodology of study. 
The Kozhikode seaport was shifted to Beypore $10 \mathrm{Km}$ south of Kozhikode city at the lower end of Beypore River to make it an all-weather seaport.

Over the years there are tremendous changes in the trade pattern, commodity, freight handling equipments, containerisation etc. The present facilities at Kozhikode seaport are not capable to take up these changes and accommodate bigger vessels.

\subsection{Objectives of the study}

The objectives of the study are as follows:

- To forecast the future freight traffic at Kozhikode seaport after development.

- $\quad$ To determine the facilities needed for future traffic.

- To determine the economic feasibility of the new seaport.

\subsection{Methodology developed for the study}

The methodology developed for the study is presented in figure 1. Two different scenarios are considered in the study namely Do-nothing scenario and the development scenario.

\section{Freight data analysis}

Historical freight data collection is the preliminary step towards the traffic forecasting. Commodity wise freight traffic data for the last 20 years were collected from the Kozhikode seaport.

\subsection{Seaport planning}

Planning of a seaport is very essential for accommodating the future freight traffic leading to the economic development of the hinterland. Proper planning will reduce the turnaround time of vessels. The seaport planning should also consider proper connection to other transportation networks like highways, railways, and waterways for increasing the transport efficiency. The facilities at a seaport are designed for the forecasted traffic. The main types of forecasting models are the regression models (causal models) and the time series models. The causal model assumes that the data to be forecasted exhibits a cause-effect relationship with the independent variable. Hence they are used when major policy changes are expected. On the other hand, the time series model assumes that a future value depends on the past values of the variable and used when there are no major policy changes.

\subsection{Inventory of the facilities at present seaport}

The Kozhikode seaport carries out the activities like freight transport, passenger transport, and fishing. Presently one lakh tonne of freight is handled at this seaport annually. The seaport is $2 \mathrm{Km}$ away from the National Highway (NH17) 
and $3 \mathrm{~km}$ from the Feroke railway station. There are two breakwaters at the river end to break the impact of waves at the berth and to train the channel. A draught of only $3.5 \mathrm{~m}$ is available at the berth. The seaport have a backup area of $6000 \mathrm{sq}$. meters, five covered warehouses of total 2800 Sq. meters area and one shed of 590 sq. meters. There are two RCC wharves, one of $152 \mathrm{~m}$ and other $160 \mathrm{~m}$ in length. Five electric wharf cranes, one of 5T capacity and four each of 3T and one forklift truck of 3T are available. There is separate passenger terminal and a fishing harbor. The present major problem at Kozhikode seaport is inadequate draught of $3.5 \mathrm{~m}$. This enables only 2000 Dead Weight Tonnage (DWT) vessels to come to berth. Hence, bigger vessels are anchored in outer sea and the freight is transported to the shore by smaller vessels incurring huge unnecessary expenditure. Thus, many commodities destined to Kozhikode are diverted to nearby major seaports resulting in unnecessary highway traffic.

\subsection{Annual freight traffic at Kozhikode seaport}

The annual time series commodity wise freight handled at Kozhikode seaport from the year 1991-92 to 2010-11is presented in table 1.

Table 1: $\quad$ Time series freight traffic.

\begin{tabular}{|l|l|l|l|l|l|l|l|}
\hline Year & $91-92$ & $92-93$ & $93-94$ & $94-95$ & $95-96$ & $96-97$ & $97-98$ \\
\hline Freight(T) & 31267 & 29109 & 32388 & 37727 & 53011 & 53152 & 44822 \\
\hline Year & $98-99$ & $99-00$ & $00-01$ & $00-01$ & $01-02$ & $02-03$ & $03-04$ \\
\hline Freight(T) & 49189 & 58515 & 89545 & 100257.5 & 79836 & 52125 & 76208.5 \\
\hline Year & $04-05$ & $05-06$ & $06-07$ & $07-08$ & $08-09$ & $10-11$ \\
\hline Freight(T) & 123763 & 66906 & 135506 & 120102 & 104672 & 107750 \\
\hline
\end{tabular}

\section{Traffic forecasting for 'Do-nothing scenario'}

Do-nothing scenario assumes no major developments and the past freight traffic growth will continue. Hence traffic forecasting for this scenario is done by time series modelling.

\subsection{Time series analysis}

In time series analysis, the independent variable is taken as time and the dependent variable as annual freight traffic (Makridakis et al. [2]). The change in annual freight traffic with respect to time is estimated. Auto correlation function is used to identify whether there exists any relationship between the successive time series data for adopting time series modelling. The auto correlation function is presented in figure 2.

The auto correlation values with time lag 1 and 2 have exceeded the critical value of 0.4383 . This infers that the value at any point of time is dependent on the values at previous two time periods. 


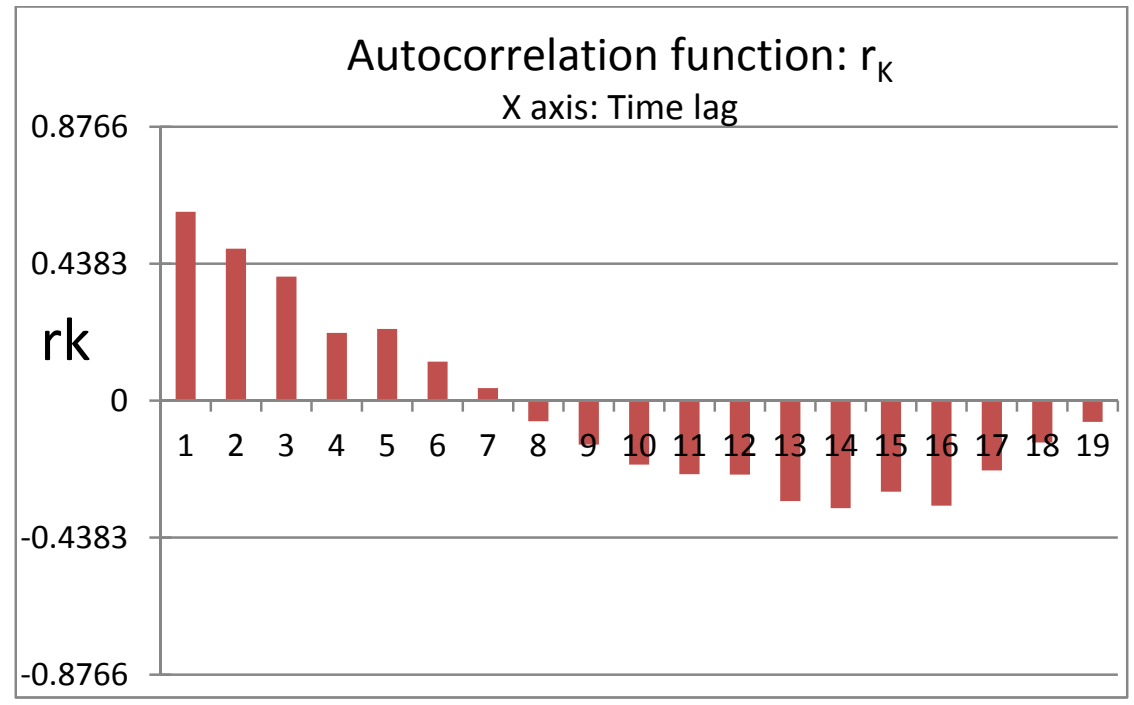

Figure 2: $\quad$ Autocorrelation function plot.

\subsection{Time series modelling}

Different models like polynomial models, exponential model, linear model, logarithmic model etc. were developed using the time series data. The time, $t$ is taken in years starting from 1 for the year 1991-92, 2 for 1992-93 and so on. The models developed are presented in table 2. The 'Percentage Root Mean Square Error' (\% RMSE) is found out for each model. Polynomial model of second order has the lowest \% RMSE value and is selected as the best model for forecasting which is presented in figure 3.

Table 2: $\quad$ Comparison of different models.

\begin{tabular}{|l|l|c|}
\hline Model & Equation & \%RMSE \\
\hline $\begin{array}{l}\text { Polynomial-second } \\
\text { order }\end{array}$ & $\begin{array}{l}\mathrm{Yt}=20359+5165.1 \mathrm{t}-16.025 \\
\mathrm{t}^{2}\end{array}$ & 23.69 \\
\hline Linear model & $\mathrm{Yt}=21593+4828.6 \mathrm{t}$ & 23.7 \\
\hline Exponential model & $\mathrm{Yt}=30226 \mathrm{e}^{0.0728 \mathrm{t}}$ & 25.2 \\
\hline Power model & $\mathrm{Yt}=21624 \mathrm{t}^{0.5191}$ & 25.5 \\
\hline Logarithmic model & $\mathrm{Yt}=3365.7+32562 \ln (\mathrm{t})$ & 27.8 \\
\hline
\end{tabular}




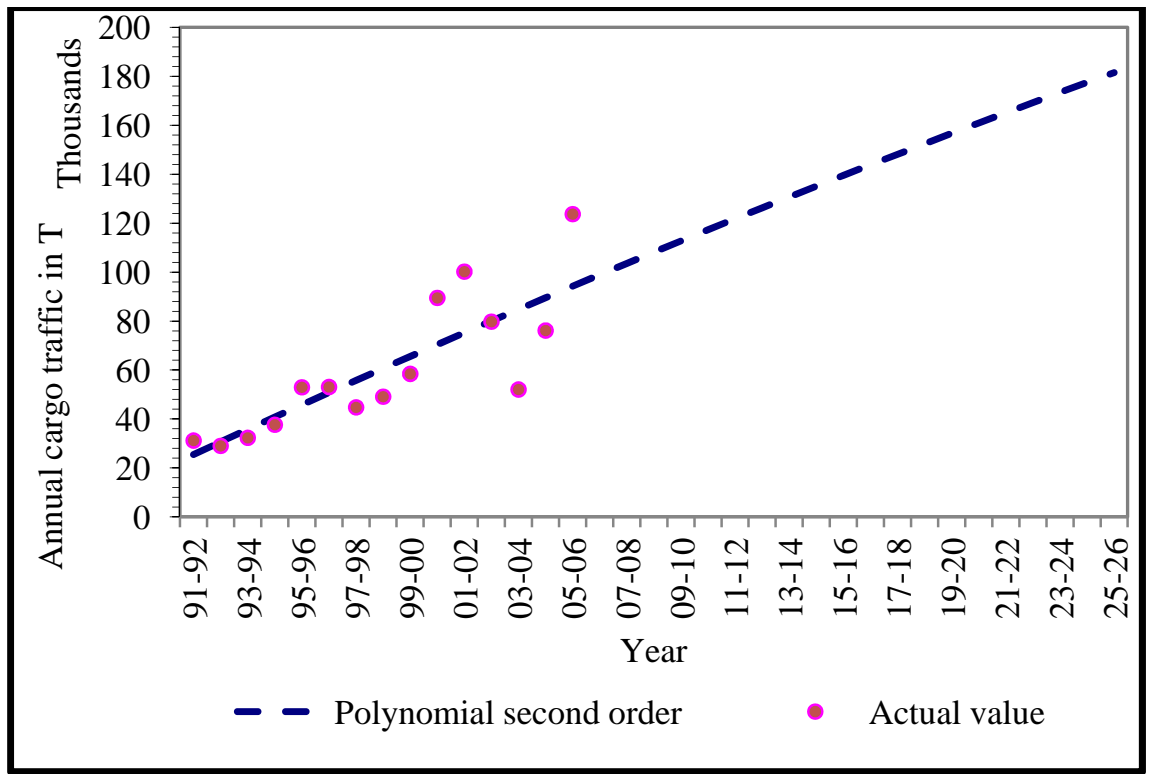

Figure 3: $\quad$ Time series forecasting of annual freight traffic.

\section{Freight traffic forecasting for 'Development' scenario}

Some freight is presently diverted to nearby major ports due to inadequate draught at Kozhikode. Availability of 15 meter draught, adequate berths and freight handling facilities will attract bigger vessels to Kozhikode. To assess this attracted freight, stated preference survey of the major shippers was conducted. The actual attracted freight may be much more than the quantity obtained from the surveys conducted, as all the shippers could not be interviewed due to lack of fund and time and some shippers have not disclosed the annual freight data. Also some freight coming from north India to Kozhikode by highways may also be diverted to coastal shipping after the port development as coastal shipping is much economical. Hence, considering all these factors the total attracted freight traffic is assessed as 1,855,072 tonnes for the year 2012-13. The total freight for development scenario is assessed as 1,981,307 tonnes by combining the traffic for the 'do-nothing' scenario and attracted traffic.

\subsection{Traffic forecasting of the attracted traffic}

The estimated attracted freight traffic is much higher than the present traffic. Hence the time series model developed for the present seaport traffic cannot be used for forecasting the attracted traffic. The freight traffic has definitely a linkage with the economic indicator 'gross state domestic product' (GSDP). Therefore, the forecasting of the attracted freight traffic was done by using the average annual growth rates of GSDP, which is presented in table 3 . The average 
annual percentage growth rate in GDP for the last 10 years from 2001-02 to 2010-11 is 7\%. This forecasted traffic is used for assessing the facilities for development scenario.

Table 3: $\quad$ Forecasting of total freight traffic.

\begin{tabular}{|r|c|c|c|}
\hline YEAR & \multicolumn{3}{|c|}{ Forecasted traffic in tonnes } \\
\hline & $\begin{array}{c}\text { Do-nothing } \\
\text { scenario }\end{array}$ & $\begin{array}{c}\text { Attracted traffic for } \\
\text { development scenario }\end{array}$ & Total traffic \\
\hline $12-13$ & 126235 & 1855072 & 1981307 \\
\hline $13-14$ & 130679 & 1984927 & 2115606 \\
\hline.. & $\ldots$ & $\ldots$ & $\ldots$ \\
\hline $22-23$ & 169233 & 3649208 & 3818440 \\
\hline
\end{tabular}

\section{Planning of the facilities by queuing theory}

Queuing theory is used to determine the number of berths required for different classes of vessels to accommodate the forecasted traffic. The arrival and the departure of the vessels are assumed to be random, following Poisson distribution. Multiple berths are considered for each class of vessels. The operating characteristics such as average queue length, average number of vessels in port, average time a vessel spends in port, average time a vessel spends waiting, probability of the port being empty (idling), are determined by considering as $\mathrm{M} / \mathrm{M} / \mathrm{N}$ system. Although there are numerous classes of vessels that operate in a seaport, for simplicity, only four common classes of vessels were considered in this study viz. 300DWT, 2000DWT, 4000DWT and 80000DWT. 300 DWT vessels are very common at the present seaport. The maximum size of vessels which can be accommodated with the present draught of $3.5 \mathrm{~m}$ is $2000 \mathrm{DWT}$. And that for $15 \mathrm{~m}$ is $80000 \mathrm{DWT}$. The length of the queue is assumed as unconstrained. The freight traffic handled by the 300DWT class vessels is assumed as $75 \%$ for $3.5 \mathrm{~m}$ draught and $10 \%$ for $15 \mathrm{~m}$ draught. The balance traffic is assumed to be distributed equally among the other class of vessels. On enquiry the turnaround time for 300, 2000, 4000 and 80000 DWT vessels are found to be 2, 2, 3, 12 days respectively. Hence the service times are calculated as $0.5,0.5,0.333$ and 0.083 vessels per day respectively.

The 'average queue waiting time' is taken as the main performance indicator in queuing theory. If the queue waiting time is more than 0.5 days the vessels may get diverted to the nearby uncongested major ports. And if it is less that 0.1 by providing more berths, the system will be uneconomical. The numbers of berths required for each class of vessels are determined based on this criterion. The queuing theory analysis is presented in table 4. The width of entrance channel is taken as $200 \mathrm{~m}$. 
Table 4: Design of facilities by queuing theory.

\begin{tabular}{|c|c|c|}
\hline & \multicolumn{2}{|c|}{ Scenarios } \\
\hline & Do Nothing & Development \\
\hline Draught (in meters) & $3.5 \mathrm{~m}$ & $15 \mathrm{~m}$ \\
\hline Expected traffic in base year 12-13 (T) & 126,235 & $1,855,072$ \\
\hline Expected cargo traffic after 10 years $(\mathrm{T})$ & 169,233 & $3,649,208$ \\
\hline Maximum vessel which can berth in DWT & 2,000 & 80,000 \\
\hline Maximum Vessel length (m) & 93 & 300 \\
\hline Traffic by 80000 DWT vessels & 0 & $1,094,762$ \\
\hline Traffic by 4000 DWT vessels & 0 & $1,094,762$ \\
\hline Traffic by 2000 DWT vessels & 42,308 & $1,094,762$ \\
\hline Traffic by 300 DWT vessels & 126,925 & 364,921 \\
\hline Annual arrival of 80000 DWT vessels & 0 & 14 \\
\hline Annual arrival of 4000 DWT vessels & 0 & 274 \\
\hline Annual arrival of 2000 DWT vessels & 21 & 547 \\
\hline Annual arrival of 300 DWT vessels & 423 & 1,216 \\
\hline Avg. daily arrival of 80000 DWT, $\lambda$ & 0.000 & 0.037 \\
\hline Avg. daily arrival of $4000 \mathrm{DWT}, \lambda$ & 0.000 & 0.750 \\
\hline Avg. daily arrival of $2000 \mathrm{DWT}, \lambda$ & 0.058 & 1.500 \\
\hline Avg. daily arrival of $300 \mathrm{DWT}, \lambda$ & 1.159 & 3.333 \\
\hline Number of berths for 80000 DWT & 0 & 3 \\
\hline Number of berths for 4000 DWT & 0 & 4 \\
\hline Number of berths for 2000 DWT & 1 & 5 \\
\hline Number of berths for 300 DWT & 4 & 9 \\
\hline Wharf length needed for one 80000 DWT & 330 & 330 \\
\hline Wharf length needed for one 4000 DWT & 110 & 110 \\
\hline Wharf length needed for one 2000 DWT & 102 & 102 \\
\hline Wharf length needed for one 300 DWT & 24 & 24 \\
\hline Total Wharf length (m) & 199 & 2,159 \\
\hline$\rho$ for $80000 \mathrm{DWT}$ & & 0.45 \\
\hline$\rho$ for $3000 \mathrm{DWT}$ & & 2.25 \\
\hline$\rho$ for $1500 \mathrm{DWT}$ & 0.12 & 3.00 \\
\hline$\rho$ for $300 \mathrm{DWT}$ & 2.32 & 6.67 \\
\hline Average waiting time for 80000 DWT & & 0.054 \\
\hline Average waiting time for 4000 DWT & & 0.413 \\
\hline Average waiting time for 2000 DWT & 0.262 & 0.236 \\
\hline Average waiting time for $300 \mathrm{DWT}$ & 0.311 & 0.268 \\
\hline
\end{tabular}


The Sustainable City VIII, Vol. 21063

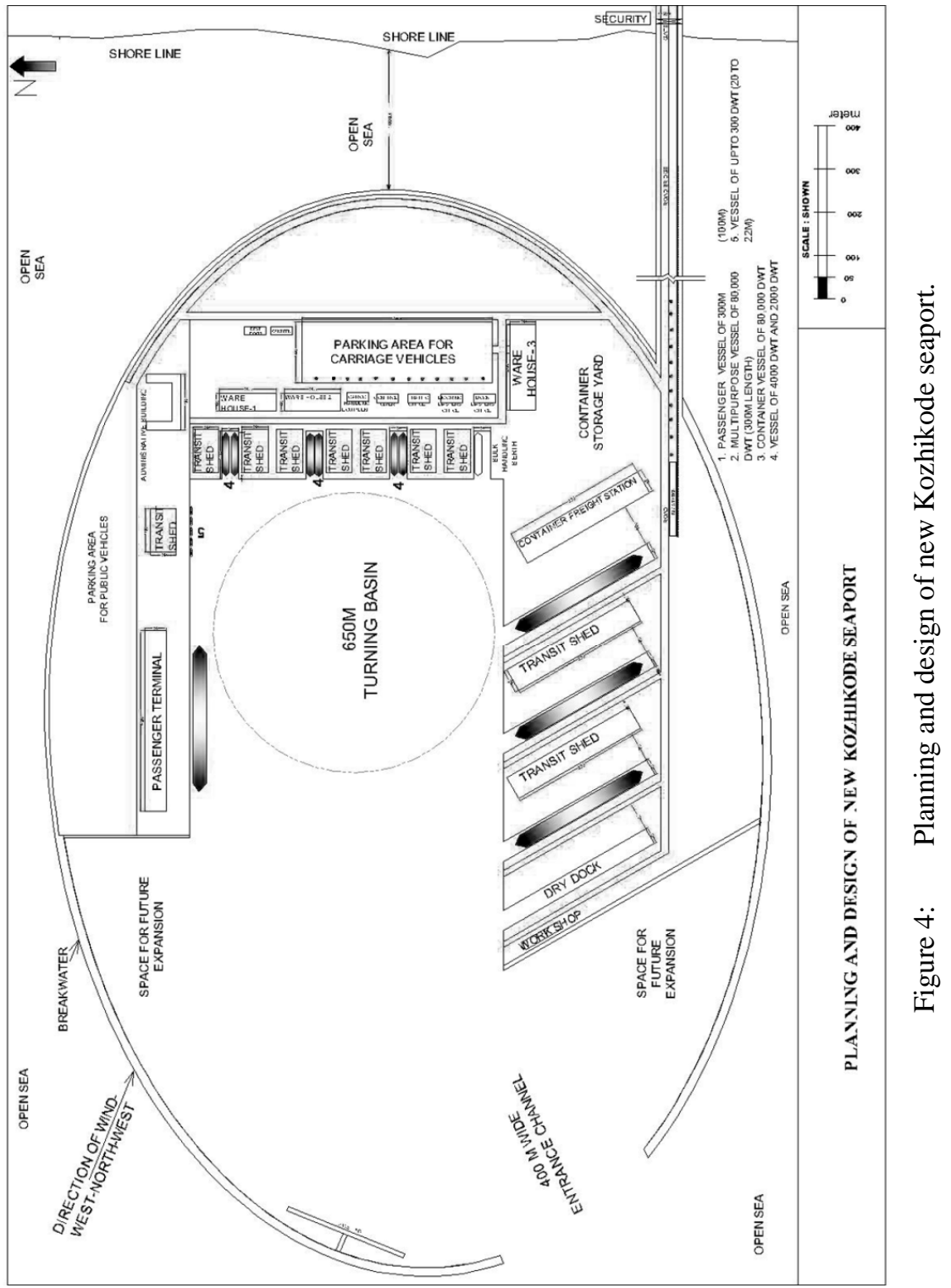


The developments needed at the seaport for the development scenario are estimated as

- $15 \mathrm{~m}$ draught for 80,000 DWT vessels.

- Three berths for 80000DTW vessels, 4 berths for 4000DWT, 5 berths for 2000DWT and 9 berths for 300DWT are required.

- Sufficient turning basin for 80000DWT vessels.

- $\quad$ Easy access to the City market.

- Good transport connectivity to highways and railways.

- Less maintenance dredging.

- Sufficient breakwaters to create a tranquil condition in the harbor.

- Sufficient wharf length, storage spaces.

Mechanised container handling facilities are needed to reduce turnaround time of vessels.

\section{Development of new Kozhikode seaport}

The development of the present Beypore seaport is not possible due to shallow foundation depth and river sedimentation. Hence a new seaport is proposed into the outer sea at Kozhikode beach (latitude of $11.24930^{\circ} \mathrm{N}$ and longitude of $75.77172^{\circ} \mathrm{E}$ ). This will avoid a lot of expenditure on dredging as natural draught is available in the outer sea. The deposition and attrition of sand in the beach can be minimized by adopting the ellipse shape in the sea minimizing environmental impacts. The planning and design of the new Kozhikode seaport is presented in the International conference, AMTID 2011 by the same author (Ansu and Dilba [3], DeF Quinn [4], Agerschou et al. [5], IS: 4651 [6], UNCTAD [7]). The total cost of developing the new seaport is estimated as Rs. 3551.68 Crores. The plan of the new seaport is presented in figure 4 .

\section{Cost benefit analysis}

Cost benefit analysis is performed to find out the feasibility of a project and for selection of the best among different alternatives. The costs and benefits are adjusted for the time value of money using discount rate and represented on a common basis of 'net present value'. Hence, the Cost Benefit Analysis is performed for the two different scenarios of Kozhikode port. The revenue is calculated for the freight traffic handled at the port based on the port revenue, Scale of rates [8]. This port revenue is increased annually based on the rate of inflation of $7 \%$. The present value factor of future cash flow is calculated at a discount rate (Rate of return) of $5 \%$. The cost benefit analysis performed is presented in table 5.

The Breakeven occurs when the net present value becomes positive and is found to be 36 years. Social and environmental benefits are not considered in the present study. The development will also reduce the unnecessary fuel consumption, highway congestion, environmental pollution etc. Many shippers 
stated that wish to ship through Kozhikode seaport after its development (Ansu and Anjaneylu [9]) as this results in savings of highway transportation costs to the nearby major ports. The annual savings to these shippers is estimated as Rs. 177.9 crores for the year 2012-13. This savings to the shippers is also not considered in the cost benefit analysis as it will not contribute to the project revenue.

Table 5: $\quad$ Cost benefit analysis.

\begin{tabular}{|c|c|c|c|c|c|c|}
\hline \multirow[t]{2}{*}{ YEAR } & \multicolumn{2}{|c|}{$\begin{array}{l}\text { Forecasted annual freight } \\
\text { traffic in tonnes }\end{array}$} & \multicolumn{2}{|c|}{$\begin{array}{l}\text { Forecasted revenue in } \\
\text { million Rs. }\end{array}$} & \multirow{2}{*}{$\begin{array}{l}\text { Net } \\
\text { present } \\
\text { value } \\
\text { in } \\
\text { million } \\
\text { Rs. }\end{array}$} & \multirow{2}{*}{$\begin{array}{l}\text { Net } \\
\text { present } \\
\text { value } \\
\text { in } \\
\text { million } \\
\text { US \$ }\end{array}$} \\
\hline & $\begin{array}{l}\text { Do- } \\
\text { nothing } \\
\text { Scenario }\end{array}$ & $\begin{array}{l}\text { Development } \\
\text { Scenario }\end{array}$ & $\begin{array}{l}\text { Do- } \\
\text { nothing } \\
\text { Scenario }\end{array}$ & $\begin{array}{l}\text { Development } \\
\text { Scenario }\end{array}$ & & \\
\hline $14-15$ & \multicolumn{3}{|c|}{ Development cost } & $-35,517$ & $\begin{array}{r}- \\
35,517\end{array}$ & -696.4 \\
\hline $14-15$ & 135091 & 2258963 & 8.8 & 146.8 & -35370 & -693.5 \\
\hline $15-16$ & 139471 & 2412014 & 9.7 & 167.8 & -35210 & -690.4 \\
\hline $16-17$ & 143819 & 2575440 & 10.7 & 191.7 & -35036 & -687.0 \\
\hline $49-50$ & 269317 & 22945010 & 186.9 & $15,923.3$ & -1919 & -37.6 \\
\hline $50-51$ & 272575 & 24535567 & 202.4 & $18,219.0$ & 1226 & 24.0 \\
\hline
\end{tabular}

\section{Conclusion}

A systematic methodology for the development of a seaport is demonstrated in this study. Large quantity of freight is diverted to the nearby major ports at Cochin and Mangalore due to the inadequate draught at the Beypore seaport of Kozhikode. This in turn causes congestion on highways from Cochin to Mangalore. The stated preference survey disclosed that the shippers prefer a seaport having a draught of $15 \mathrm{~m}$ at Kozhikode to accommodate bigger vessels. Increasing the draught to $15 \mathrm{~m}$ at the present seaport is not possible as the existing port structures have shallow foundation and will have to be demolished and reconstructed. Also maintaining the draught of $15 \mathrm{~m}$ in the river is difficult due to river sedimentation. Hence a new seaport is planned and designed to be constructed into the sea. The Cost benefit analysis is performed and the breakeven period is found out to be 36 years. This will also result in huge fuel savings, reduced highway congestion from nearby major ports, increased international trade and overall economic development. Hence the construction of new sea port is warranted for sustainable development.

\section{References}

[1] State wise number of ports, Indian Ports Association (IPA), www.ipa.nic.in

[2] Makridakis, S., Wheelwright, S C., Hyndman, R J., Forecasting Methods and Applications, John Wiley \& Sons, Inc., U.S.A, 1998. 
[3] Ansu, V., Dilba, R.K., Sustainable planning and design of new Kozhikode seaport, Int. Conf. AMTID 2011, Department of Civil Engineering, NIT Calicut. 28 to 30th September 2011.

[4] Alonzo DeF Quinn., Design and construction of ports and marine structures, McGraw-Hill, 1971.

[5] Hans Agerschou., Helge Lundgren., Torben Sorensen., Planning and design of ports and marine terminals., Wiley, 1983.

[6] Indian standard code of practice for Planning and design of ports and harbours, IS: 4651-1980.

[7] Port Development - A hand book for planners in developing countries, United Nations Conference on Trade and Development, Geneva, 1985.

[8] Scale of rates, Tariff authority for major ports, http://www.tariffauthority.gov.in/htmldocs/sor_list_Port.htm

[9] Ansu, V., Anjaneylu, M.V.L.R., Economic Appraisal of Development of an Intermediate Port - a case study of Beypore Port, Indian Port Journal, volume 39, no. 2, October 2007. 